\title{
Pollinator PREFERENCES AND THE PERSistenCE OF CROP GENES IN WILD RADISH POPULATIONS (RAPHANUS RAPHANISTRUM, BrassicaCEAe) ${ }^{1}$
}

\author{
Ted N. LeE ${ }^{2,4}$ And Allison A. SNOW 3,5 \\ ${ }^{2}$ Department of Biology, University of Michigan, 830 N. University, Ann Arbor, Michigan 48109-1048; and \\ ${ }^{3}$ Department of Plant Biology, Ohio State University, 1735 Neil Avenue, Columbus, Ohio 43214
}

\begin{abstract}
Crop-weed hybridization can potentially influence the evolutionary ecology of wild populations. Many crops are known to hybridize with wild relatives, but few studies have looked at the long-term persistence of crop genes in the wild. This study investigated one factor in the hybridization process in radish: differential pollinator visitation to wild radish (Raphanus raphanistrum) vs. crop-wild $\mathrm{F}_{1}$ hybrids $(R$. sativus $\times R$. raphanistrum). Wild genotypes had yellow flowers, a recessive single-locus trait, whereas hybrids always had white or pale pink flowers. In experimental arrays in northern Michigan, total pollinator visitation was significantly biased toward wild plants when the frequencies of wild and hybrid plants were equal. Syrphid flies, the most frequent visitors, preferred wild plants while bumble bees showed no preference. This pattern was also observed when hybrid plants were overrepresented in the array (12 hybrid:2 wild). In contrast, when hybrid plants were rare ( 2 hybrid: 12 wild), neither morph was preferred by any pollinator group. Later in the summer, pollinators were also observed in a large experimental garden with nearly equal frequencies of wild and hybrid plants. Cabbage butterflies (Pieris rapae) strongly overvisited wild plants, while bumble bees showed a slight preference for hybrids. Taken together, these studies suggest that $F_{1}$ hybrids may not be at a disadvantage with regard to pollinator visits when they occur at low frequencies or when bumble bees are frequent flower visitors. Thus, variation in the proportion of white-flowered morphs among wild radish populations could be influenced by different histories of crop-to-wild hybridization, as well as by variation in the composition of local pollinator taxa.
\end{abstract}

Key words: Brassicaceae; bumble bee; butterfly; flower color; hybridization; pollination; radish; Raphanus; syrphid.

Spontaneous hybridization between crops and their wild relatives may promote rapid evolution in weeds (e.g., Small, 1984). Recently, the greatest ecological concern regarding crop-weed hybridization has been that beneficial engineered genes (transgenes) inserted into crop plants will escape into wild populations via pollen dispersal, thus potentially increasing the invasiveness of natural relatives (see reviews in Raybould and Gray, 1993; Snow and Morán Palma, 1997). Crop-weed hybridization occurs frequently in a wide range of potentially weedy plants, including canola (Brassica rapa, Adler et al., 1993; B. napus $\times$ B. campestris, Jørgensen and Andersen, 1995), sorghum and johnsongrass (Sorghum bicolor $\times$ S. halapense, Arriola and Ellstrand, 1996), sunflower (Helianthus annuus, Arias and Rieseberg, 1994), squash (Cucurbita texana $\times$ C. pepo, Kirkpatrick and Wilson, 1988), and wild radish (Raphanus sativus, Klinger, Elam, and Ellstrand, 1991; Klinger and Ellstrand,

\footnotetext{
${ }^{1}$ Manuscript received 2 December 1996; revision accepted 15 July 1997.

The authors thank Sara Beresford, Dave Karowe, and Joe Holomuski for their invaluable contributions to this study; Jeffrey Karron and an anonymous reviewer for comments on the manuscript; Jeff Conner for seeds from Bay City, Michigan; Dave Cowan for assistance with insect identification; and Bob VandeKopple and the University of Michigan Biological Station staff for valuable logistical assistance. This study was supported by a grant from NSF's Research Experience for Undergraduates program, the Biddeford Fund (OSU), and the University of Michigan Biological Station.

${ }^{4}$ Author for correspondence, current address: Department of Ecology and Evolutionary Biology, University of Arizona, Tucson, AZ 857210066 (e-mail: tedl@u.arizona.edu).

${ }^{5}$ Also at the University of Michigan Biological Station, Pellston, MI, 49769.
}

1994). In this study, we focus on another wild radish species, Raphanus raphanistrum, which is capable of hybridizing with wild and cultivated $R$. sativus (Panetsos and Baker, 1967).

Wild radish (Raphanus raphanistrum) is an agricultural weed from Eurasia that occurs on several continents, including northeastern North America (Holm et al., 1979). As a self-incompatible annual, it is an obligate outcrosser that relies on insect pollinators for successful reproduction (e.g., Stanton et al., 1989; Conner and Rush, 1996; Kercher and Conner, 1996). $R$. raphanistrum is polymorphic for flower color (yellow or white), and although the white allele is dominant to yellow in a singlelocus system (Kay, 1978; Stanton et al., 1989), whiteflowered plants are often rare or absent in wild populations (Kercher and Conner, 1996; A. Snow, unpublished data). The presence of these white morphs may be a result of hybridization with cultivated radish ( $R$. sativus, Kay, 1984; Kercher and Conner, 1996). If this is the case, different histories of hybridization between wild and cultivated radish could alter flower color frequencies in wild populations. The goal of this study was to determine whether differential pollinator visitation to these flower color morphs could also influence the spread and persistence of crop genes, especially the white allele and others that are linked to this locus.

Pollinators often discriminate between petal color variants of polymorphic species (Phlox drummondii, Levin, 1972a, b; Levin and Brack, 1995; Delphinium nelsonii, Waser and Price, 1981, 1983; Ipomoea purpurea, Brown and Clegg, 1984; Schoen and Clegg, 1985; Epperson and Clegg, 1987; R. sativus, Stanton, 1987; $R$. raphanistrum, Stanton, Snow, and Handel, 1986; Stanton et al., 1989). 
Such behavior may influence the relative reproductive success of color morphs by biasing maternal and paternal contributions to the next generation towards the more frequently visited morph. For example, Pieris rapae (cabbage butterfly) strongly preferred the yellow-flowered morph of wild radish over the white (Kay, 1976) and this preference affected the relative paternal success of the two morphs (Stanton, Snow, and Handel, 1986; Stanton et al., 1989). The present study is unique in that (1) we test for effects of flower color frequencies on pollinator behavior, (2) we provide data on additional types of pollinators of wild radish, and (3) we focus on how pollinator preferences influence the introgression of genes from cultivated radish ( $R$. sativus) into wild populations of $R$. raphanistrum. The dynamics of pollen movement between these two species has not been studied previously, despite the fact that $R$. sativus is commonly grown on farms and in home gardens across the United States and hybridization between them is probable (Panetsos and Baker, 1967; Kercher and Conner, 1996).

In this study, we compared visitation rates to crop-wild $\mathrm{F}_{1}$ hybrids ( $R$. sativus $\times R$. raphanistrum, white or pale pink flowers) vs. purely wild plants ( $R$. raphanistrum, yellow flowers) to address the following questions: (1) Do pollinators prefer one petal color variant over another? (2) Are preferences consistent among pollinator taxa? (3) Are pollinator preferences influenced by the relative frequencies of wild and hybrid plants in a population?

\section{MATERIALS AND METHODS}

Source of plants and inheritance of flower color-Seeds of $R$. raphanistrum were collected in Bay City, Michigan (same population as described in Kercher and Conner, 1996). Yellow-flowered plants grown from these seeds were hand-pollinated with pollen from each other or from cultivated radish plants (Scarlet Globe: a commonly grown cultivar in this region) to obtain wild and hybrid $F_{1}$ progeny for the experiments described below. Flowers of Scarlet Globe radishes were white, pale pink, or pink. All wild $\times$ wild progeny had yellow flowers as expected, while most of the interspecific hybrids were white-flowered. Although a few hybrid plants had pale pink flowers, for brevity the hybrids will be referred to as white-flowered below.

Preliminary studies showed that the locus determining white or yellow flower color may be the same in $R$. raphanistrum and $R$. sativus. When seven interspecific hybrids were backcrossed with wild, yellowflowered $R$. raphanistrum maternal plants, each of these seed families included both white- and yellow-flowered progeny, as expected with a single Mendelian locus. Furthermore, Scarlet Globe ( $R$. sativus) appears to be homozygous for the dominant white allele because crosses between 20 crop plants and 20 yellow-flowered wild plants resulted in more than 400 progeny that were always white or pale pink rather than yellow. Pink flower color in $R$. sativus is controlled by a different gene and its inheritance is more complex (Stanton, 1987). Some populations of $R$. raphanistrum include rare plants with bronze-colored flowers (a mixture of yellow and pink), and these may represent introgression of the gene for pink flowers from the crop (e.g., Kercher and Conner, 1996). All of the arrays described hereafter were similar in the proportion of hybrids that were pale pink $(<30 \%)$ rather than white.

Experimental design-To determine whether flower color influences pollinator visitation, pollinator movements were recorded within experimental radish populations at the University of Michigan Biological Station, Pellston, Michigan, in 1996. These populations consisted of seven white- and seven yellow-flowered (7w:7y) potted radish plants $\underline{3}$

$\begin{array}{ccccc} & 2 & & \underline{4} & \\ \underline{1} & & \underline{8} & & 5 \\ & \underline{7} & & 9 & \\ & & 12 & & 10 \\ & 11 & & \underline{13} & \\ & & 14 & \end{array}$

Fig. 1. Array for experimental radish populations $(7 y: 7 w)$ where underlined numbers signify white-flowered plants and plain numbers are yellow.

arranged in an array of four interconnecting hexagons (Fig. 1). All plants were comparable in size and flower number and were spaced $0.75 \mathrm{~m}$ from adjacent plants. We did not attempt to artificially maintain equal numbers of flowers on each plant because the plants were also being monitored for flower production and fruit set (A. Snow, unpublished data). The positions of white and yellow plants were rotated among trials to prevent possible edge effects.

To assess whether pollinator preferences were frequency dependent, two additional array designs were used. Rather than containing equal numbers of white and yellow plants, each array was composed of either 12 white and two yellow plants (12w:2y, yellows rare), or two white and 12 yellow plants ( $2 \mathrm{w}: 12 \mathrm{y}$, whites rare). In these designs, rare plants were placed at positions 7 and 9 in the hexagonal array (Fig. 1). Four replicates of each of the three array designs were conducted in random order over a 12-d period, and we observed one array design per day for $\sim 4.5 \mathrm{~h}$.

Pollinator observations-For each flower visitor, we recorded the taxon (bumble bee, syrphid fly, or other), flower color of the plant visited, number of flowers visited per plant, and the position of the plant within the array. Visits were recorded only when the insect probed the flower for nectar and/or pollen. Preferences were determined by comparing the number of visits to each color morph with expected values based on flower color frequencies in each array (chi-square tests). Expected values for plant-to-plant visits were calculated from ratios of white- and yellow-flowered plants, while those for individual flower visits were calculated from the numbers of white and yellow flowers on all plants in the array for each day. Day-to-day consistency of pollinator visits to each array was assessed by $\mathrm{R} \times \mathrm{C}$ tests of independence (Sokal and Rohlf, 1981).

To determine whether pollinators moved assortatively among the two petal color variants, plant-to-plant transitions were recorded during observations of the $7 \mathrm{w}: 7 \mathrm{y}$ arrays. This array was designed such that the four interior plants were surrounded by three plants of either flower color so that pollinators could choose between equivalent numbers of adjacent yellow- and white-flowered plants (Fig. 1). Furthermore, transitions among color morphs from edge plants were, on average, nearly equally likely (frequency of $w-w$ and $y-y=0.24$, frequency of $w-y$ and $y-w=0.26$ ). Observed numbers of each transition type were compared to expected values based on the null hypothesis of random movement among colors (chi-square tests).

To assess pollinator behavior under more natural conditions, pollinators were also observed visiting a large garden plot (established for another experiment) consisting of ten rows of 20 radish plants per row, with equal numbers of wild and $F_{1}$ hybrids randomly distributed in each row. Hour-long observations were made on two consecutive days in early September 1996, when we recorded visits to plants with at least three open flowers ( 82 wild plants and 73 hybrids). Plant-to-plant transitions were recorded for Pieris rapae butterflies, which were not pres- 
TABLE 1. Summary of day-to-day consistency for visits to plants within each array design. $\mathrm{R} \times \mathrm{C}$ tests of independence (Sokal and Rohlf, 1981) were performed for each pollinator group and all pollinators pooled. In the $7 \mathrm{w}: 7 \mathrm{y}$ and $2 \mathrm{w}: 12 \mathrm{y}$ designs, separate data for the "syrphid" and "other" categories were available only for three of the four trials. "NS" indicates no significance at the $P<$ 0.05 level.

\begin{tabular}{clllc}
\hline \hline Array design & Pollinator group & $G$ & df & $P$ \\
\hline 7w: $7 \mathrm{y}$ & bumble bee & 2.09 & 3 & $\mathrm{NS}$ \\
& syrphid fly & 8.59 & 2 & $<0.025$ \\
& other & 3.93 & 2 & $\mathrm{NS}$ \\
& all & 3.62 & 3 & $\mathrm{NS}$ \\
12w: $\mathrm{w} y$ & bumble bee & 0.71 & 3 & $\mathrm{NS}$ \\
& syrphid fly & 1.75 & 3 & $\mathrm{NS}$ \\
& other & 7.41 & 3 & $\mathrm{NS}$ \\
& all $\mathrm{w}: 12 \mathrm{y}$ & 3.27 & 3 & $\mathrm{NS}$ \\
& bumble bee & 1.67 & 3 & $\mathrm{NS}$ \\
& syrphid fly & 0.10 & 2 & $\mathrm{NS}$ \\
& other & 0.14 & 2 & $\mathrm{NS}$ \\
& all & 1.19 & 3 & $\mathrm{NS}$ \\
\hline
\end{tabular}

ent until late August, and also for bumble bees. Preferences for both pollinator classes were determined by chi-square tests.

In all analyses, each pollinator visit was considered an independent event despite the possibility that individual preferences might differ. This important limitation is a common problem of nearly every study of this kind, but since we are more concerned with pollen flow among plants, irrespective of which pollinator facilitates it, this method seems justifiable. Furthermore, we noticed that each pollinator type was represented by at least ten or more individuals, so it is unlikely that individual differences among pollinators had much effect on our results.

\section{RESULTS}

Insect visitors - The most abundant pollinators within the experimental arrays were syrphid flies and bumble bees, which collectively made up $>80 \%$ of all visits. At least eight different syrphid species (Syrphidae) were observed visiting flowers and comprised 53\% of total visits; these included Eristalis tenax, Metasyrphus americanus, and Toxomerus spp. Bumble bees (Bombus spp.) were the second most abundant pollinators and made $28 \%$ of total visits, while "other" flower visitors accounted for the remaining $19 \%$. This group was composed predominantly of small halictid bees (Halictidae), but additional visitors included honey bees (Apis mellifera), bee flies (Anthrax analis, Bombylius spp.), a red milkweed beetle (Tetraopes tetraophthalmus), a spotted cucumber beetle (Diabrotica undecimpunctata), a cabbage butterfly (Pieris rapae), and a ruby-throated hummingbird (Archilochus colubris). These visits accounted for $<3 \%$ of the total visits to all arrays.

In general, each pollinator group's plant-to-plant visitation patterns were consistent over the four trials of each array design (Table 1). The only exception was for syrphid visits to the $7 \mathrm{w}: 7 \mathrm{y}$ array design, where variation among days was significant $(G=8.59$, df $=2, P<$ $0.025)$. This variation did not involve preference reversals, however, and since there was no other significant day-to-day variation, data for each pollinator group were pooled across days for further statistical analyses. Pollinator visits for each day of observation are summarized in the Appendix.

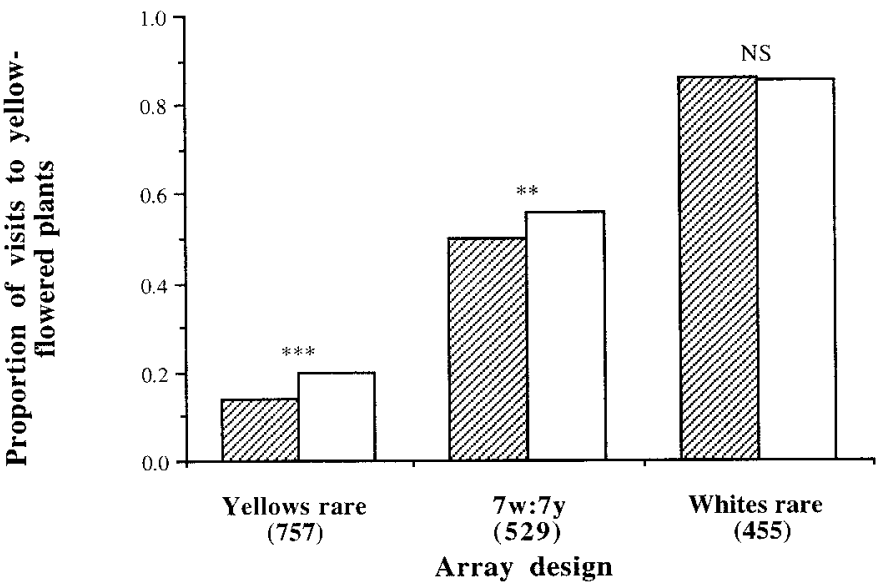

Fig. 2. Proportion of visits to yellow-flowered plants by all pollinators. Chi-square tests were used to determine significant differences between observed (open bars) and expected (hatched bars) visitation. Sample sizes are given in parentheses beneath each array design. "NS" indicates that the proportion of observed visits were not significantly different than expected; a double asterisk (**) indicates significance at the $P<0.005$ level, while a triple asterisk (***) corresponds to a significance level of $P<0.001$.

Effects of flower color and frequency on visitationFlower color significantly influenced pollinator visitation to the $7 \mathrm{w}: 7 \mathrm{y}$ array design. When data from all four days were pooled, total pollinator visitation was significantly biased toward yellow-flowered plants $\left(X^{2}=9.00\right.$, df $=$ $1, P<0.005$; Fig. 2). This preference for yellow was also seen for flower-to-flower visits (Table 2). Responses to flower color varied among pollinator classes. Bumble bees did not discriminate between white- and yellowflowered plants, while syrphid flies significantly overvisited yellow-flowered plants $\left(\mathrm{X}^{2}=9.89\right.$, df $=1, P<$ 0.005; Fig. 3), and other visitors showed a similar but nonsignificant trend (Fig. 3). No pollinator group showed

TABLE 2. Summary of pooled pollinator visits to individual flowers (as opposed to plants). Data are presented for every day of observation and each array design. Expected values were based on the number of white and yellow flowers present in the array, which varied somewhat for each day of observation, although plant frequencies were $7 \mathrm{w}: 7 \mathrm{y}, 2 \mathrm{w}: 12 \mathrm{y}$, or $2 \mathrm{w}: 12 \mathrm{y}$. "NS" indicates no significance at the $P<0.05$ level.

\begin{tabular}{|c|c|c|c|c|c|c|}
\hline \multirow[b]{2}{*}{ Date } & \multirow{2}{*}{$\begin{array}{l}\text { Total } \\
\text { visits }\end{array}$} & \multicolumn{3}{|c|}{$\begin{array}{c}\text { Proportion of } \\
\text { visits to yellow flowers }\end{array}$} & \multirow[b]{2}{*}{$x^{2}$} & \multirow[b]{2}{*}{$P$} \\
\hline & & Obs. & & Exp. & & \\
\hline \multicolumn{7}{|c|}{ A) Equal frequencies } \\
\hline $26 \mathrm{Jul}$ & 286 & 0.57 & $>$ & 0.49 & 7.97 & $<0.005$ \\
\hline $31 \mathrm{Jul}$ & 418 & 0.49 & $\approx$ & 0.45 & 2.44 & NS \\
\hline 2 Aug & 370 & 0.63 & $>$ & 0.43 & 59.59 & $<0.001$ \\
\hline 6 Aug & 345 & 0.63 & $>$ & 0.40 & 73.48 & $<0.001$ \\
\hline \multicolumn{7}{|c|}{ B) Yellows rare } \\
\hline 1 Aug & 345 & 0.21 & $>$ & 0.15 & 11.26 & $<0.001$ \\
\hline $2 \mathrm{Aug}$ & 408 & 0.16 & $>$ & 0.10 & 22.73 & $<0.001$ \\
\hline 7 Aug & 578 & 0.20 & $>$ & 0.08 & 117.70 & $<0.001$ \\
\hline 8 Aug & 404 & 0.15 & $>$ & 0.09 & 18.35 & $<0.001$ \\
\hline \multicolumn{7}{|c|}{ C) Whites rare } \\
\hline $27 \mathrm{Jul}$ & 224 & 0.85 & $\approx$ & 0.84 & 0.11 & NS \\
\hline $30 \mathrm{Jul}$ & 424 & 0.90 & $>$ & 0.84 & 14.01 & $<0.001$ \\
\hline 3 Aug & 211 & 0.81 & $>$ & 0.75 & 4.36 & $<0.05$ \\
\hline 5 Aug & 215 & 0.94 & $>$ & 0.77 & 33.01 & $<0.001$ \\
\hline
\end{tabular}



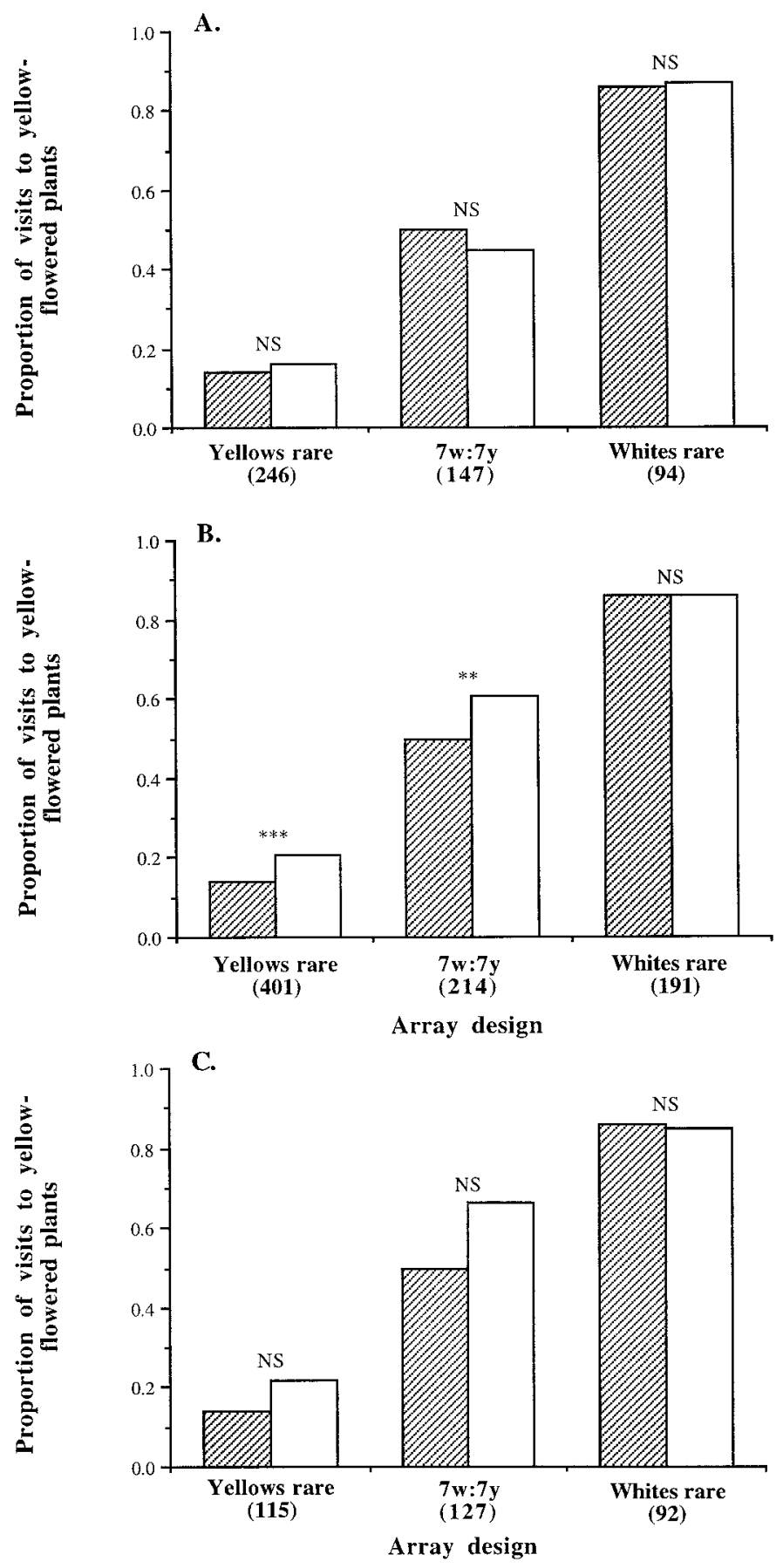

Fig. 3. Proportion of visits to yellow-flowered plants by: (A) bumble bees, (B) syrphids, and (C) other flower visitors (mainly halictid bees). Chi-square tests were used to determine significant differences between observed (open bars) and expected (hatched bars) visitation. Sample sizes are given in parentheses beneath each array design. "NS" indicates that the proportion of observed visits were not significantly different than expected; a double asterisk (**) indicates significance at the $P<0.005$ level, while a triple asterisk (***) corresponds to a significance level of $P<0.001$.

any consistent preferences for white- vs. pink-flowered hybrids.

Preference for yellow-flowered plants was frequency dependent. When yellow plants were rare or in equal fre-
TABLE 3. Summary of late-season cabbage butterfly ( $P$. rapae) and bumble bee (Bombus spp.) visits to yellow-flowered plants in the experimental garden plot. Expected values were calculated from the proportion of yellow- vs. white-flowered plants with more than three open flowers in the plot on the day of observation.

\begin{tabular}{|c|c|c|c|c|c|c|}
\hline \multirow[b]{2}{*}{ Date } & \multirow{2}{*}{$\begin{array}{l}\text { Total } \\
\text { visits }\end{array}$} & \multicolumn{3}{|c|}{$\begin{array}{c}\text { Proportion of } \\
\text { visits to yellow morph }\end{array}$} & \multirow[b]{2}{*}{$x^{2}$} & \multirow[b]{2}{*}{$P$} \\
\hline & & Obs. & & Exp. & & \\
\hline \multicolumn{7}{|c|}{ Cabbage butterflies } \\
\hline 7 Sep & 196 & 0.80 & $>$ & 0.53 & 55.64 & $<0.001$ \\
\hline $8 \mathrm{Sep}$ & 275 & 0.73 & $>$ & 0.53 & 42.96 & $<0.001$ \\
\hline \multicolumn{7}{|c|}{ Bumble bees } \\
\hline 8 Sep & 197 & 0.45 & $<$ & 0.53 & 4.84 & $<0.05$ \\
\hline
\end{tabular}

quencies with whites, they received a significantly greater proportion of the total visits than expected $\left(\mathrm{X}^{2}=22.48\right.$, df $=1, P<0.001 ; \mathrm{X}^{2}=9.00$, df $=1, P<0.005$, respectively; Fig. 2), but when white plants were rare (2w:12y design), no preference was seen (Figs. 2, 3). For all array designs, however, the flower-to-flower visits were still significantly biased towards yellow flowers (Table 2).

Due to the difficulty of recording plant-to-plant transitions for syrphid flies, data on assortative mating are restricted to bumble bees. A total of 132 transitions were recorded over all four trials of the $7 \mathrm{w}: 7 \mathrm{y}$ array design. Of these, $48 \%$ were made between yellow and white plants and $52 \%$ between like colors (w-w or $\mathrm{y}-\mathrm{y}$ ). Analysis of observed and expected transition frequencies revealed that bumble bees moved randomly among color morphs $\left(\mathrm{X}^{2}=4.70, \mathrm{df}=3, P<0.5\right)$.

Late-season visits to garden plot-Visits to the garden plot by cabbage butterflies were strongly biased toward yellow-flowered plants, which received 50 and $37 \%$ more visits than expected on two days of observation, respectively $\left(\mathrm{X}^{2}=55.64\right.$, df $=1, P<0.001 ; \mathrm{X}^{2}=42.96$, df $=1, P<0.001$; Table 3). By contrast, bumble bees slightly overvisited white- and pink-flowered hybrid plants on the one day they were observed $\left(\mathrm{X}^{2}=4.84\right.$, df $=1, P<0.05$; Table 3 ).

\section{DISCUSSION}

Flower color preferences of different pollinator taxa-This study shows that some pollinator taxa discriminated against crop-wild hybrid radish. In experimental arrays where hybrid (white-flowered) and wild (yellow-flowered) plants were present in equal proportions, plant-to-plant movements by a mixture of pollinator species showed a slight advantage for wild plants. Syrphid flies, which were the most frequent insect visitors to the experimental arrays, made $\sim 1.5$ times more visits to yellow-flowered plants than to white; halictid bees showed a similar trend, though it was not statistically significant. The second most abundant visitors to our arrays were bumble bees, which moved randomly among the two color variants. In the garden plot, however, bumble bees showed a significant preference for white- and pink-flowered hybrid plants on the one day they were observed. In 1995, we also detected a slight but statistically significant preference by bumble bees for $F_{1}$ hybrids on three out of four days of observation (A. 
Snow, unpublished data). Although we do not know why this preference for white was seen on some days but not others, it is clear that bumble bees never preferred yellow-flowered plants, unlike syrphid flies, cabbage butterflies, or halictid bees.

Although cabbage butterfly (Pieris rapae) data were limited to two days of garden plot observations, we found that $P$. rapae preferred wild plants over hybrids by as much as 1.5:1.0. These data are consistent with those of Stanton et al. (1989) and Kay (1976), who found that Pieris rapae discriminated against white-flowered $R$. raphanistrum in favor of the yellow morph (by 1.5:1.0). Stanton et al. (1989) and Kay (1976) also reported preferential visitation to the yellow morphs by syrphid flies, but in both studies syrphids made up relatively small percentages of total visits $(<5 \%)$. Honey bees were infrequent visitors to our experimental plants, although they are sometimes abundant in natural populations (A. Snow, personal observation). In California populations of $R$. $s a$ tivus, honey bees did not discriminate between white- and yellow-flowered plants (Stanton, 1987).

Since seed set in wild radish populations is probably not pollen limited (Stanton et al., 1989), pollinator preferences most likely have a larger impact on male reproductive success than on the female function of its hermaphroditic flowers. By overvisiting yellow-flowered plants, pollinators may distribute more pollen from these plants to receptive stigmas on other plants. This is consistent with the findings of Stanton et al. (1989), who showed that differences in the paternal success of white vs. yellow $R$. raphanistrum morphs were closely correlated to differences in pollinator visitation rates. Therefore, in hybridizing radish populations where the main pollinators are $P$. rapae, syrphid flies or halictid bees, the yellow-flowered morph will likely have higher paternal success than the white.

Influence of flower color frequencies on pollinator preference-The impact of pollinator preferences on the reproductive success of different petal color variants also depends on the relative frequencies of the morphs within a population. Results from this study show that preferences for yellow plants were relatively constant when white plants were common or dominant in the population, but when white plants were rare no preferences were seen, indicating that neither color morph was at a selective advantage. However, when we take into account the flower-to-flower transitions, yellow flowers were still favored when whites were rare. It is difficult to interpret this discrepancy between flower-to-flower visits and plant-to-plant visits. Because radish is self-incompatible, repeated visits within the same plant do not contribute to female reproductive success and may reduce pollen dispersal, so we place greater emphasis on plant-to-plant pollinator movements, which may better represent actual outcrossing rates.

Epperson and Clegg (1987) showed a parallel but opposite visitation pattern by pollinators of white- and purple-flowered morning glory (Ipomoea purpurea). They found that bumble bees, the most common visitor, showed no preference with respect to flower color when white-flowered plants were common or dominant in the experimental populations, but discriminated against the white petal morph when it was rare. They attributed this preference to bumble bees' innate preference for "beepurple" flowers. Regardless of the specific mechanism influencing pollinator preferences, it is important to consider the implications of frequency-dependent preferences in relation to the spread and persistence of crop genes in wild populations.

Introgression of crop genes into $R$. raphanistrumMany factors could influence rates of hybridization between cultivated radish ( $R$. sativus) and its wild, weedy relative ( $R$. raphanistrum). Because these plants share the same geographical range, hybridization is surely possible, however, introgression rates will depend on spatial and phenological separation between the crop and wild populations. Klinger, Elam, and Ellstrand (1991) showed that gene flow was greatest between adjoining populations of cultivated and wild $R$. sativus but still occurred between populations up to $1000 \mathrm{~m}$ apart. This is a typical leptokurtic pattern for pollen-mediated gene flow in outcrossing plants, and it suggests that the frequency of $F_{1}$ hybrids in wild populations will be negatively correlated with distance from the crop. Flowering times of wild and cultivated radishes are likely to overlap during at least a portion of the growing season because there is a great deal of variation in the times of establishment and the onset of flowering in wild $R$. raphanistrum, and large plants often bloom for 4-6 wk (A. Snow, personal observation). Panetsos and Baker (1967) found that when $\mathrm{F}_{1}$ interspecific hybrids ( $R$. sativus $\times R$. raphanistrum) and wild plants were established at the same time, the hybrids began flowering $\sim 2$ wk later on average than wild plants. Our wild and hybrid plants showed similar staggered phenology, but there was still adequate overlap in flowering times to allow introgression to occur, as evidenced by the availability of plants for our arrays.

Partial sterility in $F_{1}$ hybrids will also affect the rate at which crop genes move into wild populations of $R$. raphanistrum. Interspecific crosses between $R$. sativus and $R$. raphanistrum result in $\mathrm{F}_{1}$ progeny that are heterozygous for a reciprocal translocation that causes abortion of pollen and seeds (Panetsos and Baker, 1967). In our plants, $\sim 40-50 \%$ of hybrid pollen grains were aborted, and a similar trend was seen in the proportion of aborted seeds (A. Snow, unpublished data). The mean number of fruits produced by hybrids was similar to that of wild plants, but lower gametophytic success in the hybrids should decrease the overall reproductive success of these plants. In subsequent generations, crop genes that are tightly linked to the locus with the reciprocal translocation may be less likely to persist in wild populations due to selection against plants that are heterozygous at this locus.

This study shows that pollinator preferences can also influence the persistence of crop genes in wild populations of $R$. raphanistrum. Because several major pollinator taxa discriminate against white-flowered morphs, crop genes may be effectively selected against in some wild populations. This selection would affect all crop genes in the $\mathrm{F}_{1}$ generation, assuming that these plants inherit the dominant allele for white flowers, and could eventually lead to decreased frequencies of crop genes that are linked to this flower color locus. However, we 
found that selection against the white morph decreased when these plants were rare. When this occurs, the allele for white petals could persist at low frequencies in wild populations over longer periods of time. Also, in populations where bumble bees are important pollinators, the white flower color from the crop plant could be maintained at relatively high frequencies because these pollinators either prefer hybrids or show no preference. Periodic introgression from crop plants may also help maintain the polymorphism. In conclusion, whether the whiteflowered morph found in populations of $R$. raphanistrum is introduced by introgression and/or mutation, we found that the frequency of this morph is likely to be influenced by the species composition of local pollinators.

\section{LITERATURE CITED}

Adler, L. S., K. Wickler, P. S. Wyndham, C. R. Linder, AND J. SchmitT. 1993. Potential for persistence of genes escaped from canola: germination cues in crop, wild and crop-wild hybrid Brassica rapa. Functional Ecology 7: 736-745.

ARIAS, D. M., AND L. H. RieseberG. 1994. Gene flow between cultivated and wild sunflower. Theoretical Applied Genetics 89: 655-660.

Arriola, P. E., AND N. C. Ellstrand. 1996. Crop-to-weed gene flow in the genus Sorghum (Poaceae): spontaneous interspecific hybridization between johnsongrass, Sorghum halapense, and crop sorghum, S. bicolor. American Journal of Botany 83: 1153-1160.

BRown, B. A., AND M. T. ClegG. 1984. Influence of flower color polymorphism on genetic transmission in a natural population of the common morning glory, Ipomoea purpurea. Evolution 38: 796803.

CONNER, J. K., AND S. RUSH. 1996. Effects of flower size and number on pollinator visitation to wild radish, Raphanus raphanistrum. Oecologia 105: 509-516.

EpPerson, B. K., AND M. T. ClegG. 1987. Frequency-dependent variation for outcrossing rate among flower-color morphs of Ipomoea purpurea. Evolution 41: 1302-1311.

Holm, L., J. V. Pancho, J. P. Herberger, and D. L. Plucknett. 1979. A geographical atlas of world weeds. Wiley, New York, NY.

JøRGENSEN, R., AND B. ANDERSEN. 1995. Spontaneous hybridization between oilseed rape (Brassica napus) and weedy Brassica campestris: a risk of growing genetically modified oilseed rape. American Journal of Botany 81: 1169-1175.

KAY, Q. O. N. 1976. Preferential pollination of yellow-flowered morphs of Raphanus raphanistrum by Pieris and Eristalis spp. Nature 261: 230-232.

. 1978. The role of preferential and assortative pollination in the maintenance of flower colour polymorphisms. In A. J. Richards [ed.], The pollination of flowers by insects. Academic Press, New York, NY.

- 1984. Variation, polymorphism and gene-flow within species.
In V. H. Heywood and D. M. Moore [eds.], Current concepts in plant taxonomy, 181-199. Academic Press, London.

KerChER, S., AND J. K. CONNER. 1996. Patterns of genetic variability within and among populations of wild radish, Raphanus raphanistrum (Brassicaceae). American Journal of Botany 83: 1416-1421.

KiRKPATRICK, K. J., AND H. D. Wilson. 1988. Interspecific gene flow in Cucurbita: C. texana vs. C. pepo. American Journal of Botany 75: 519-527.

Klinger, T., D. R. Elam, and N. C. Ellstrand. 1991. Radish as a model system for the study of engineered gene escape rates via crop-weed mating. Conservation Biology 5: 531-535.

, and N. C. Ellstrand. 1994. Engineered genes in wild populations: fitness of weed-crop hybrids of Raphanus sativus. Ecological Applications 4: 117-120.

LEVIN, D. A. 1972a. Low frequency disadvantage in the exploitation of pollinators by corolla variants in Phlox. American Naturalist 106: 453-460.

- 1972b. The adaptedness of corolla-color variants in experimental and natural populations of Phlox drummondii. American Naturalist 106: 57-70.

- AND E. T. BRACK. 1995. Natural selection against white petals in Phlox. Evolution 49: 1017-1022.

PAnetsos, C. A., AND H. G. BAKer. 1967. The origin of variation in "wild" Raphanus sativus (Cruciferae) in California. Genetica 38: $243-274$

Raybould, A. F., AND A. J. Gray. 1993. Genetically modified crops and hybridization with wild relatives: a UK perspective. Journal of Applied Ecology 30: 199-219.

Schoen, D. J., AND M. T. ClegG. 1985. The influence of flower color on outcrossing rate and male reproductive success in Ipomoea purpurea. Evolution 39: 1242-1249.

SMALl, E. 1984. Hybridization in the domesticated-weed-wild complex. In W. F. Grant [ed.], Plant biosystematics, 195-210. Academic Press, Toronto.

Snow, A. A., AND P. Morán Palma. 1997. Commercialization of transgenic plants: potential ecological risks. BioScience 47: 86-96.

SokAL, R. R., AND F. J. Rohlf. 1981. Biometry. W. H. Freeman, San Francisco, CA.

Stanton, M. L. 1987. Reproductive biology of petal color variants in wild populations of Raphanus sativus. I. Pollinator response to color morphs. American Journal of Botany 74: 178-187.

, A. A. SNOw, And S. N. HAndel. 1986. Floral evolution: attractiveness to pollinators increases male fitness. Science 232: $1625-1627$.

- - , AND J. BERECZKY. 1989. The impact of flowercolor polymorphism on mating patterns in experimental populations of wild radish (Raphanus raphanistrum L.). Evolution 43: 335-346.

Waser, N. M., AND M. V. Price. 1981. Pollinator choice and stabilizing selection for flower color in Delphinium nelsonii. Evolution 35: 376-390.

- AND . 1983. Pollinator behaviour and natural selection for flower color in Delphinium nelsonii. Nature 302: 422-424. 
APPENDIX. Summary of visits to yellow-flowered morphs for each day of observation and each array design. On 26 and 27 July, syrphids were not recorded separately from other non-bumble bee pollinators and, therefore, are included in the "other" category for these days. Cells marked with a dash (-) indicate that there were insufficient sample sizes to perform chi-square tests. An "F" indicates visits to flowers, while a " $P$ " indicates visits to plants, and "NS" denotes no significance at the $P<0.05$ level.

\begin{tabular}{|c|c|c|c|c|c|c|c|}
\hline \multirow[b]{2}{*}{ Pollinator } & \multirow[b]{2}{*}{ Date } & & \multirow{2}{*}{$\begin{array}{l}\text { Total } \\
\text { visits }\end{array}$} & \multicolumn{2}{|c|}{$\begin{array}{l}\text { Proportion of } \\
\text { visits to } \\
\text { yellow morph }\end{array}$} & \multirow[b]{2}{*}{$x^{2}$} & \multirow[b]{2}{*}{$P$} \\
\hline & & & & Obs. & Exp. & & \\
\hline \multicolumn{8}{|c|}{ Equal frequencies } \\
\hline \multirow[t]{8}{*}{ Bumble bee } & $26 \mathrm{Jul}$ & $\mathrm{F}$ & 227 & 0.55 & 0.49 & 3.34 & NS \\
\hline & & $\mathrm{P}$ & 62 & 0.50 & 0.50 & 0.00 & NS \\
\hline & $31 \mathrm{Jul}$ & $\mathrm{F}$ & 246 & 0.44 & 0.45 & 0.22 & NS \\
\hline & & $\mathrm{P}$ & 46 & 0.44 & 0.50 & 0.78 & NS \\
\hline & 4 Aug & $\mathrm{F}$ & 114 & 0.39 & 0.43 & 0.94 & NS \\
\hline & & $\mathrm{P}$ & 29 & 0.35 & 0.50 & 2.79 & NS \\
\hline & 6 Aug & $\mathrm{F}$ & 21 & 0.43 & 0.40 & 0.07 & NS \\
\hline & & $\mathrm{P}$ & 10 & 0.50 & 0.50 & 0.00 & NS \\
\hline \multirow[t]{6}{*}{ Syrphid } & $31 \mathrm{Jul}$ & $\mathrm{F}$ & 144 & 0.53 & 0.45 & 4.18 & $<0.05$ \\
\hline & & $\mathrm{P}$ & 58 & 0.45 & 0.50 & 0.31 & NS \\
\hline & 4 Aug & $\mathrm{F}$ & 155 & 0.84 & 0.43 & 105.64 & $<0.001$ \\
\hline & & $\mathrm{P}$ & 53 & 0.70 & 0.50 & 8.32 & $<0.005$ \\
\hline & 6 Aug & $\mathrm{F}$ & 256 & 0.67 & 0.40 & 78.03 & $<0.001$ \\
\hline & & $\mathrm{P}$ & 103 & 0.65 & 0.50 & 9.33 & $<0.005$ \\
\hline \multirow[t]{8}{*}{ Other } & $26 \mathrm{Jul}$ & $\mathrm{F}$ & 59 & 0.66 & 0.49 & 6.91 & $<0.01$ \\
\hline & & $\mathrm{P}$ & 53 & 0.70 & 0.50 & 8.32 & $<0.005$ \\
\hline & $31 \mathrm{Jul}$ & $\mathrm{F}$ & 28 & 0.72 & 0.45 & 7.90 & $<0.005$ \\
\hline & & $\mathrm{P}$ & 26 & 0.69 & 0.50 & 3.85 & $<0.05$ \\
\hline & 4 Aug & $\mathrm{F}$ & 101 & 0.58 & 0.43 & 9.79 & $<0.005$ \\
\hline & & $\mathrm{P}$ & 59 & 0.58 & 0.50 & 1.37 & NS \\
\hline & 6 Aug & $\mathrm{F}$ & 59 & 0.59 & 0.40 & 9.18 & $<0.005$ \\
\hline & & $\mathrm{P}$ & 42 & 0.45 & 0.50 & 0.38 & NS \\
\hline \multirow[t]{8}{*}{ All } & $26 \mathrm{Jul}$ & $\mathrm{F}$ & 286 & 0.57 & 0.49 & 7.97 & $<0.005$ \\
\hline & & $\mathrm{P}$ & 115 & 0.59 & 0.50 & 3.84 & NS \\
\hline & $31 \mathrm{Jul}$ & $\mathrm{F}$ & 418 & 0.49 & 0.45 & 2.44 & NS \\
\hline & & $\mathrm{P}$ & 130 & 0.49 & 0.50 & 0.03 & NS \\
\hline & 4 Aug & $\mathrm{F}$ & 370 & 0.63 & 0.43 & 59.59 & $<0.001$ \\
\hline & & $\mathrm{P}$ & 141 & 0.57 & 0.50 & 3.13 & NS \\
\hline & 6 Aug & $\mathrm{F}$ & 345 & 0.63 & 0.40 & 73.48 & $<0.001$ \\
\hline & & $\mathrm{P}$ & 154 & 0.59 & 0.50 & 2.55 & NS \\
\hline \multicolumn{8}{|l|}{ Yellows rare } \\
\hline \multirow[t]{8}{*}{ Bumble bee } & 1 Aug & $\mathrm{F}$ & 139 & 0.14 & 0.15 & 0.19 & NS \\
\hline & & $\mathrm{P}$ & 44 & 0.18 & 0.14 & 0.64 & NS \\
\hline & 2 Aug & $\mathrm{F}$ & 260 & 0.12 & 0.10 & 1.78 & NS \\
\hline & & $\mathrm{P}$ & 86 & 0.14 & 0.14 & 0.00 & NS \\
\hline & 7 Aug & $\mathrm{F}$ & 198 & 0.08 & 0.08 & 0.05 & NS \\
\hline & & $\mathrm{P}$ & 49 & 0.14 & 0.14 & 0.00 & NS \\
\hline & 8 Aug & $\mathrm{F}$ & 278 & 0.12 & 0.09 & 3.54 & NS \\
\hline & & $\mathrm{P}$ & 67 & 0.18 & 0.14 & 0.85 & NS \\
\hline \multirow[t]{8}{*}{ Syrphid } & 1 Aug & $\mathrm{F}$ & 164 & 0.30 & 0.15 & 30.85 & $<0.001$ \\
\hline & & $\mathrm{P}$ & 85 & 0.16 & 0.14 & 0.43 & NS \\
\hline & 2 Aug & $\mathrm{F}$ & 89 & 0.36 & 0.10 & 66.63 & $<0.001$ \\
\hline & & $\mathrm{P}$ & 49 & 0.24 & 0.14 & 4.48 & $<0.05$ \\
\hline & 7 Aug & $\mathrm{F}$ & 365 & 0.26 & 0.08 & 166.11 & $<0.001$ \\
\hline & & $\mathrm{P}$ & 213 & 0.21 & 0.14 & 7.84 & $<0.01$ \\
\hline & 8 Aug & $\mathrm{F}$ & 97 & 0.21 & 0.09 & 15.99 & $<0.001$ \\
\hline & & $\mathrm{P}$ & 54 & 0.24 & 0.14 & 4.55 & $<0.05$ \\
\hline \multirow[t]{8}{*}{ Other } & 1 Aug & $\mathrm{F}$ & 42 & 0.12 & 0.15 & 0.32 & NS \\
\hline & & $\mathrm{P}$ & 38 & 0.13 & 0.14 & 0.02 & NS \\
\hline & 2 Aug & $\mathrm{F}$ & 59 & 0.07 & 0.10 & 0.68 & NS \\
\hline & & $\mathrm{P}$ & 38 & 0.08 & 0.14 & 0.02 & NS \\
\hline & 7 Aug & $\mathrm{F}$ & 15 & 0.40 & 0.08 & - & - \\
\hline & & $\mathrm{P}$ & 14 & 0.36 & 0.14 & - & - \\
\hline & 8 Aug & $\mathrm{F}$ & 32 & 0.31 & 0.09 & - & - \\
\hline & & $\mathrm{P}$ & 25 & 0.28 & 0.14 & - & - \\
\hline
\end{tabular}

APPENDIX. Continued.

\begin{tabular}{|c|c|c|c|c|c|c|c|}
\hline \multirow[b]{2}{*}{ Pollinator } & \multirow[b]{2}{*}{ Date } & & \multirow{2}{*}{$\begin{array}{l}\text { Total } \\
\text { visits }\end{array}$} & \multicolumn{2}{|c|}{$\begin{array}{l}\text { Proportion of } \\
\text { visits to } \\
\text { yellow morph }\end{array}$} & \multirow[b]{2}{*}{$x^{2}$} & \multirow[b]{2}{*}{$P$} \\
\hline & & & & Obs. & Exp. & & \\
\hline \multirow[t]{8}{*}{ All } & \multirow[t]{2}{*}{1 Aug } & $\mathrm{F}$ & 345 & 0.21 & 0.15 & 11.26 & $<0.001$ \\
\hline & & $\mathrm{P}$ & 178 & 0.21 & 0.14 & 7.98 & $<0.005$ \\
\hline & \multirow[t]{2}{*}{2 Aug } & $\mathrm{F}$ & 408 & 0.16 & 0.10 & 22.74 & $<0.001$ \\
\hline & & $\mathrm{P}$ & 143 & 0.19 & 0.14 & 2.83 & NS \\
\hline & \multirow[t]{2}{*}{7 Aug } & $\mathrm{F}$ & 578 & 0.20 & 0.08 & 117.70 & $<0.001$ \\
\hline & & $\mathrm{P}$ & 276 & 0.20 & 0.14 & 9.07 & $<0.005$ \\
\hline & \multirow[t]{2}{*}{8 Aug } & $\mathrm{F}$ & 404 & 0.15 & 0.09 & 18.35 & $<0.001$ \\
\hline & & $\mathrm{P}$ & 143 & 0.20 & 0.14 & 4.68 & $<0.05$ \\
\hline \multicolumn{8}{|l|}{ Whites rare } \\
\hline \multirow[t]{8}{*}{ Bumble bee } & \multirow[t]{2}{*}{27 Jul } & $\mathrm{F}$ & 108 & 0.77 & 0.84 & 4.11 & $<0.05$ \\
\hline & & $\mathrm{P}$ & 30 & 0.87 & 0.86 & 0.01 & NS \\
\hline & \multirow[t]{2}{*}{30 Jul } & $\mathrm{F}$ & 124 & 0.90 & 0.84 & 4.09 & $<0.05$ \\
\hline & & $\mathrm{P}$ & 45 & 0.91 & 0.86 & 1.08 & NS \\
\hline & \multirow[t]{2}{*}{3 Aug } & $\mathrm{F}$ & 68 & 0.66 & 0.75 & 2.68 & NS \\
\hline & & $\mathrm{P}$ & 19 & 0.79 & 0.86 & 0.79 & NS \\
\hline & \multirow[t]{2}{*}{5 Aug } & $\mathrm{F}$ & 0 & - & - & - & - \\
\hline & & $\mathrm{P}$ & 0 & - & - & - & - \\
\hline \multirow[t]{6}{*}{ Syrphid } & \multirow[t]{2}{*}{$30 \mathrm{Jul}$} & $\mathrm{F}$ & 278 & 0.90 & 0.84 & 6.87 & $<0.01$ \\
\hline & & $\mathrm{P}$ & 94 & 0.86 & 0.86 & 0.00 & NS \\
\hline & \multirow[t]{2}{*}{3 Aug } & $\mathrm{F}$ & 80 & 0.88 & 0.75 & 6.67 & $<0.01$ \\
\hline & & $\mathrm{P}$ & 52 & 0.85 & 0.86 & 0.08 & NS \\
\hline & \multirow[t]{2}{*}{5 Aug } & $\mathrm{F}$ & 149 & 0.95 & 0.77 & 26.15 & $<0.001$ \\
\hline & & $\mathrm{P}$ & 45 & 0.87 & 0.86 & 0.02 & NS \\
\hline \multirow[t]{8}{*}{ Other } & \multirow[t]{2}{*}{27 Jul } & $\mathrm{F}$ & 116 & 0.92 & 0.84 & 5.86 & $<0.025$ \\
\hline & & $\mathrm{P}$ & 78 & 0.90 & 0.86 & 0.91 & NS \\
\hline & \multirow[t]{2}{*}{$30 \mathrm{Jul}$} & $\mathrm{F}$ & 22 & 0.91 & 0.84 & - & - \\
\hline & & $\mathrm{P}$ & 19 & 0.89 & 0.86 & - & - \\
\hline & \multirow[t]{2}{*}{3 Aug } & $\mathrm{F}$ & 63 & 0.89 & 0.75 & 6.48 & $<0.025$ \\
\hline & & $\mathrm{P}$ & 44 & 0.86 & 0.86 & 0.01 & NS \\
\hline & 5 Aug & $\mathrm{F}$ & 66 & 0.91 & 0.77 & 7.21 & $<0.01$ \\
\hline & & $\mathrm{P}$ & 29 & 0.86 & 0.86 & 0.00 & NS \\
\hline All & 27 Jul & $\mathrm{F}$ & 224 & 0.85 & 0.84 & 0.11 & NS \\
\hline & & $\mathrm{P}$ & 108 & 0.89 & 0.86 & 0.75 & NS \\
\hline & $30 \mathrm{Jul}$ & $\mathrm{F}$ & 424 & 0.90 & 0.84 & 14.01 & $<0.001$ \\
\hline & & $\mathrm{P}$ & 158 & 0.88 & 0.86 & 0.51 & NS \\
\hline & 3 Aug & $\mathrm{F}$ & 211 & 0.81 & 0.75 & 4.36 & $<0.05$ \\
\hline & & $\mathrm{P}$ & 115 & 0.84 & 0.86 & 0.26 & NS \\
\hline & $5 \mathrm{Aug}$ & $\mathrm{F}$ & 215 & 0.94 & 0.77 & 33.01 & $<0.001$ \\
\hline & & $\mathrm{P}$ & 74 & 0.87 & 0.86 & 0.02 & NS \\
\hline
\end{tabular}

